Pesq. Vet. Bras. 37(4):319-324, abril 2017 DOI: $10.1590 / \mathrm{S} 0100-736 \mathrm{X} 2017000400004$

\title{
Animal movement network analysis as a tool to map farms serving as contamination source in cattle cysticercosis ${ }^{1}$
}

\author{
Samuel C. Aragão ${ }^{2 *}$, Pier K.R.K. Ito ${ }^{3 *}$, Silvana C. Paulan², Yuri T. Utsunomyia ${ }^{4}$, \\ José H.H. Grisi Filho ${ }^{5}$ and Cáris M. Nunes ${ }^{3 * *}$
}

\begin{abstract}
Aragão S.C., Ito P.K.R.K., Paulan S.C., Utsunomyia Y.T., Grisi Filho J.H.H. \& Nunes C.M. 2017. Animal movement network analysis as a tool to map farms serving as contamination source in cattle cysticercosis. Pesquisa Veterinária Brasileira 37(4):319-324. Unesp, Universidade Estadual Paulista "Júlio de Mesquita Filho", Laboratório de Bioquímica e Biologia Molecular, Departamento de Apoio Produção e Saúde Animal, Faculdade de Medicina Veterinária de Araçatuba, Rua Clóvis Pestana 793, Araçatuba, SP 16050-680, Brazil. E-mail: caris@fmva.unesp.br

Bovine cysticercosis is a problem distributed worldwide that result in economic losses mainly due to the condemnation of infected carcasses. One of the difficulties in applying control measures is the identification of the source of infection, especially because cattle are typically acquired from multiple farms. Here, we tested the utility of an animal movement network constructed with data from a farm that acquires cattle from several other different farms to map the major contributors of cysticercosis propagation. Additionally, based on the results of the network analysis, we deployed a sanitary management and drug treatment scheme to decrease cysticercosis' occurrence in the farm. Six farms that had commercial trades were identified by the animal movement network and characterized as the main contributors to the occurrence of cysticercosis in the studied farm. The identification of farms with a putative risk of Taenia saginata infection using the animal movement network along with the proper sanitary management and drug treatment resulted in a gradual decrease in cysticercosis prevalence, from $25 \%$ in 2010 to $3.7 \%$ in 2011 and $1.8 \%$ in 2012 . These results suggest that the animal movement network can contribute towards controlling bovine cysticercosis, thus minimizing economic losses and preventing human taeniasis.
\end{abstract}

INDEX TERMS: Animal movement network, cattle, cysticercosis, Taenia saginata, disease control, traceability.

\footnotetext{
${ }^{1}$ Received on December 18, 2015.

Accepted for publication on December 5, 2016.

*These authors contributed equally for this research.

${ }^{2}$ Programa de Pós-Graduação em Ciência Animal, Faculdade de Medicina Veterinária de Araçatuba, Universidade Estadual Paulista "Júlio de Mesquita Filho" (Unesp), Rua Clóvis Pestana 793, Araçatuba, SP 16050-680, Brazil.

${ }^{3}$ Laboratório de Bioquímica e Biologia Molecular, Departamento de Apoio Produção e Saúde Animal, Faculdade de Medicina Veterinária de Araçatuba, Unesp, Rua Clóvis Pestana 793, Araçatuba, SP 16050-680, Brazil. **Corresponding author: caris@fmva.unesp.br

${ }^{4}$ Programa de Pós-Graduação em Medicina Veterinária, Faculdade de Ciências Agrárias e Veterinárias de Jaboticabal, Unesp, Via de Acesso Prof. Paulo Donato Castellane s/n, Jaboticabal, SP 14884-900, Brazil.

${ }^{5}$ Laboratório de Epidemiologia e Bioestatística, Departamento de Medicina Veterinária Preventiva e Saúde Animal, Faculdade de Medicina Veterinária e Zootecnia, Universidade de São Paulo (USP), Av. Prof. Dr. Orlando Marques de Paiva 87, São Paulo, SP 05508-000, Brazil.
}

RESUMO.- [Rede de movimentação animal como ferramenta para mapear fazendas fontes de contaminação para a cisticercose em gado.] A cisticercose bovina é um problema distribuído mundialmente e que resulta em perdas econômicas, principalmente devido à condenação de carcaças infectadas. Uma das dificuldades em se controlar esta zoonose no Brasil é a prática de aquisição de bovinos de múltiplas fazendas, tornando quase impossível a identificação da fazenda de origem do gado infectado, onde as medidas de controle devem ser aplicadas. Objetivou-se avaliar uma rede de movimentação animal construída com dados de uma fazenda de gado de corte que adquire animais de diferentes locais, com o objetivo de mapear as fazendas que mais contribuíam para a propagação da cisticercose. Adicionalmente, com base na análise da rede de movimentação, manejo sanitário e protocolo de tratamento adequa- 
dos foram aplicados para diminuir a ocorrência de cisticercose na fazenda em estudo. Seis propriedades que tinham trocas comerciais foram identificadas pela rede de movimentação de bovinos e caracterizadas como as principais contribuintes para a ocorrência da cisticercose na fazenda em estudo. A identificação de fazendas com risco de infecção por Taenia saginata por meio da rede de movimentação animal juntamente com o manejo sanitário e protocolo de tratamento adequados resultaram em diminuição gradual da prevalência da cisticercose de $25 \%$, em 2010 , para $3,7 \%$ em 2011 e 1,8\% em 2012. Estes resultados sugerem que a estratégia de análise da rede de movimentação do gado, associadas ao manejo sanitário e tratamento adequados podem contribuir para o controle da cisticercose bovina, minimizando assim as perdas econômicas e prevenindo a teníase humana.

TERMOS DE INDEXAÇÃO: Rede de movimentação animal, cisticercose, bovinos, Taenia saginata, controle de doenças, rastreabilidade.

\section{INTRODUCTION}

Bovine cysticercosis is a worldwide spread parasitic disease caused by the larval stage of Taenia saginata, one major cause of economic loss in the beef cattle industry. The taeniasis-cysticercosis complex is also a widespread public health issue often associated to sanitary problems, poor hygiene habits and consumption of raw or undercooked beef (Lloyd 2014). Common factors contributing to this universal distribution include the parasite eggs spreading by human feces together with their high survival periods in the environment, poor sewage treatment, grazing farm systems, contamination of water sources by human waste and deficient meat inspection protocols (Dorny \& Praet 2007, Rossi et al. 2015).

In Brazil, one of the measures adopted to prevent human infection is the carcass sanitary inspection at slaughterhouses followed by the appropriate destination of infected carcasses (Brasil 1997). Furthermore, slaughterhouses also act as a source of statistical and nosogeographical data for the occurrence of bovine cysticercosis. By joining these data with animal traceability information, it is possible to quantify and define areas in which the disease occurs (Guimarães-Peixoto et al. 2012).

One of the difficulties in controlling bovine cysticercosis in Brazil is the fact that animals are typically acquired from multiple farms, which compromises the identification of the origin of the infected cattle. Hence, traceability could be a handful tool to control not only this disease but many others since the process consists in tracing back information of an animal product through the beef cattle chain. However, bovine and bubaline traceability in Brazil is only mandatory if meat is to be exported to the European Community (Brasil 2006a).

On the other hand, Animal Movement Permits (AMPs) are currently one of the main tools for traceability in Brazil. The AMP is an official and compulsory document for any animal movement and retains information on the origin, destination, purpose, species and number of animals being transported (Brasil 2006b). However, AMPs do not allow individual traceability, since the information concerns animal lots and their movement (Grisi-Filho et al. 2013).

A basic network structure contains a set of nodes/vertices connected by edges/links between them. Networks offer both a visual and mathematical interpretation to data, capturing and describing the structure of interactions (Keeling \& Eames 2005, Keeling et al. 2010). Examples of network analysis applied to cattle movement data include network-based epidemiological model for detection of a disease outbreak (Reis et al. 2007) , assessment of pathogen dynamics on a spatiotemporal structure (Kao et al. 2006), epidemiological models of Foot and Mouth disease spread in Great Britain (Green et al. 2006), risk evaluation for potential disease spread (Natale et al. 2009, Ribeiro-Lima et al. 2015), and infectious disease surveillance (Amaku et al. 2015).This study aimed at testing the utility of an animal movement network constructed with data from a farm that acquires cattle from several other different farms to map the major contributors of cysticercosis propagation. Based on the results of the network analysis, control measures were applied to decrease cysticercosis' occurrence in the studied farm.

\section{MATERIALS AND METHODS}

Area studied The studied area is a beef cattle farm (S 20 $5^{\prime}$ 20.98" W $\left.052^{\circ} 7^{\prime} 07.49^{\prime \prime}\right)$, located in the Mato Grosso do Sul state. We selected this farm because it is located in the central-western region of Brazil, which occupies a prominent position in national livestock and agriculture production: it has 79 municipalities baring almost 50 thousand officially registered farms and a cattle herd of more than 20 million animals, the fourth largest herd in the country (IBGE 2015).

The studied farm was monitored for a 3-year period and during that period the production system was based on cattle feedlot of male steers reared under grazing conditions. Animals were divided into lots of 200 animals and maintained in a grazing system of Brachiaria spp. pasture until they reach a mean weight of $400 \mathrm{~kg}$. At the feedlot, fattening steers received a mixture of corn silage, soybean, cottonseed meal, commercial protein and mineral salt compositions for up to 90 days. After that, they were commercialized with an expected mean weight of $530 \mathrm{~kg}$. From the epidemiological point of view, it is important to mention that the animals were acquired from multiple sources and are mainly composed of crossbred dairy steers, aged between 4 and 36 months old. Water provided to the animals was captured from a water spring and pumped into a central tank from where it was distributed to the pastures and feedlot. Only three pens allowed direct access to the river and natural ponds. Due to the importance of the definitive host in this disease, it is worthy to mention that thirty-five people inhabited the studied area during the aforementioned period. These workers were living in brick houses with treated water and septic tanks.

Bovine cysticercosis treatment. Until 2010, cattle deworming on the studied farm was conducted by the subcutaneous application of $17 \%$ albendazol sulphoxide $(7.5 \mathrm{mg} / \mathrm{kg}) 30$ days before entering the feedlots, and a second dose 30 days after. In 2011 and for the following years, it was implemented a protocol that comprised 4 subcutaneous applications of $15 \%$ albendazol sulphoxide $(7.5 \mathrm{mg} / \mathrm{kg}), 60$ and 30 days before entering the feedlot, at the day that animals entered the feedlot, and 30 days after. All animals were slaughtered at least 40 days after the last treatment, following the manufacturer's recommendations. 
Sanitary education. Its primary objective was to provide information and highlight basic concepts of the disease and its relation to personal hygiene, fecal contamination of soil and water sources and eating habits. Three talks were given to all farm employees during the period, as well as seventeen meetings and nineteen practical talks concerning bovine deworming and freezing meat from slaughtered animals that were supplied for direct consumption by its employees.

Cattle movement networks. Cattle movement data were provided by the official Brazilian Agencies of the states of Mato Grosso do Sul, São Paulo, Minas Gerais and Goiás. The data is a summarized version of all Animal Movement Permits (AMP) issued by the studied farm and six other that maintained business relations with it during 2010, 2011 and 2012. Each row of the data table contained the following information: AMP identification and issued date, municipality, producer and farm name for both the source and destination. To derive movements from this data, each livestock holding facility was used as a node in the network, being uniquely identified by assigning codes to its municipality, owner and holding names. Each edge connecting two nodes was represented by issued AMPs, where the municipalities of origin (tail) and destination (tip) were used to derive movement direction. The resulting joint information was interpreted as a static directed network of cattle movement where each node represented an origin or destination, and edges represented AMPs. A node became infected only if an AMP was issued indicating that an animal lot (infected) was moved from a given node A (origin) to a node $\mathrm{B}$ (destination). The contrary (B to A) was true if, and only if, there was another AMP indicating the opposite way. In this network, the distance between two nodes (livestock holdings) was defined as the smallest number of directed edges (issued AMPs) required to connect the two.

Farm network and structure. Some network measures have epidemiological importance, such as the network diameter, modularity, weighted in and out degree and betweenness centrality (Keeling et al. 2010). Network diameter is the longest of all path lengths of a network and its modularity is a measure of the strength in which nodes divide into clusters. The number of adjacent edges arriving to a node and the number of edges going out of it, are, respectively, the in and out degrees of that node. The number of edges with the same origin and destination weights these measures. Betweenness centrality is the number of the shortest paths from all nodes in the network to all others that pass through a given node. All data manipulation and conversion to a network compliant set of nodes and edges were performed using R v3.3.0 (Development Core Team 2011) and all network properties, visualization and components structure were evaluated using the open source software Gephi v0.8.2 (Leonard et al. 2004).

Cysticercosis data and statistical analysis. The Federal Inspection Service (Serviço de Inspeção Federal, SIF) provided the number of slaughtered steers and the number of carcasses affected by live Taenia saginata cysts for the studied farm, during the period between 2010 and 2012. These were obtained from the records of the carcasses sanitary inspection at the slaughterhouses, that is, the anatomopathological examination of the carcass muscles and specific tissues such as masseter muscles, tongue, heart and diaphragm (Brasil 1997). By analyzing the affected animal AMPs, it was possible to trace back the farms that had sold the affected lots to the farm in this study. The Two Sample Binomial Proportions test was used to evaluate if there was a statistically significant difference between bovine cysticercosis occurrences by year. All statistical analysis was carried out by using R software (Development Core Team 2011).

\section{RESULTS}

The studied farm slaughtered 3,721 steers during the period between 2010 and 2012 with an observed decrease of the number of infected carcasses with live Taenia saginata cysts and a significant difference $(\mathrm{p} \leq 0.05)$ for the cysticercosis occurrence among the years (Table 1). The inward cattle movement of this farm showed that node \#3 (Table 2) was the major contributor given the number of animals (818) commercialized through the whole period.

More than one thousand Animal Movement Permits were issued during the studied period showing where the cattle were last located and to where they were destined. After analysis, it resulted in a bovine movement network with 429 nodes, 1,303 edges and a network diameter equal to 5. Nodes were distributed in 101 municipalities, 407 farms, 14 slaughterhouses and 8 livestock auction markets. The network diameter indicates the distance between the furthest pair of nodes. Given the modularity class, the network was divided into 7 clusters/communities with strong preferential trade among them (Fig.1A). For each of these communities there is a central node, indicated by its betweenness centrality (Fig.1B) and the highest out-degree (Fig.1D). The studied area is indicated by node \#1 and presented the highest in-degree (Fig.1C).

Table 1. Bovine cysticercosis occurrence in a beef cattle farm given the number of carcasses with live cysts identified by sanitary inspection of slaughtered animals during a 3-year period

\begin{tabular}{lcccccc}
\hline \multirow{2}{*}{ Year } & \multicolumn{2}{c}{ Slaughtered animals } & & \multicolumn{2}{c}{ Carcasses with live cysts } \\
\cline { 2 - 3 } \cline { 5 - 6 } & $\mathrm{n}$ & $\%$ & & $\mathrm{n}$ & $\%$ \\
\hline 2010 & 742 & 19.9 & & 185 & $24.9 \mathrm{a}$ \\
2011 & 837 & 22.5 & & 31 & $3.7 \mathrm{~b}$ \\
2012 & 2142 & 57.6 & & \multicolumn{2}{c}{39} & $1.8 \mathrm{c}$ \\
Total & \multicolumn{2}{c}{3,721} & & \multicolumn{2}{c}{255}
\end{tabular}

Different letters show statistically significant difference $(p=\leq 0.05)$.

Table 2. Number (n) of cattle acquired by the studied farm (node \#1) during the 3 -year period according to its age range and origin node

\begin{tabular}{cccccc}
\hline \multirow{2}{*}{ Node } & Year & \multicolumn{3}{c}{ Age (months) } & Total (n) \\
\cline { 3 - 5 } & & 0 to 12 & 12 to 24 & 24 to 36 & \\
\hline \multirow{2}{*}{2} & 2010 & 0 & 0 & 0 & 0 \\
& 2011 & 0 & 0 & 0 & 0 \\
3 & 2012 & 0 & 5 & 30 & 35 \\
& 2010 & 647 & 113 & 48 & 808 \\
& 2011 & 0 & 10 & 0 & 10 \\
4 & 2012 & 0 & 0 & 0 & 0 \\
& 2010 & 50 & 10 & 0 & 60 \\
& 2011 & 0 & 0 & 0 & 0 \\
5 & 2012 & 0 & 0 & 0 & 0 \\
& 2010 & 0 & 0 & 0 & 0 \\
& 2011 & 31 & 13 & 0 & 44 \\
6 & 2012 & 0 & 0 & 0 & 0 \\
& 2010 & 85 & 35 & 0 & 120 \\
& 2011 & 0 & 0 & 0 & 0 \\
7 & 2012 & 0 & 0 & 0 & 0 \\
& 2010 & 64 & 15 & 0 & 79 \\
& 2011 & 0 & 0 & 0 & 0 \\
& 2012 & 0 & 0 & 0 & 0
\end{tabular}



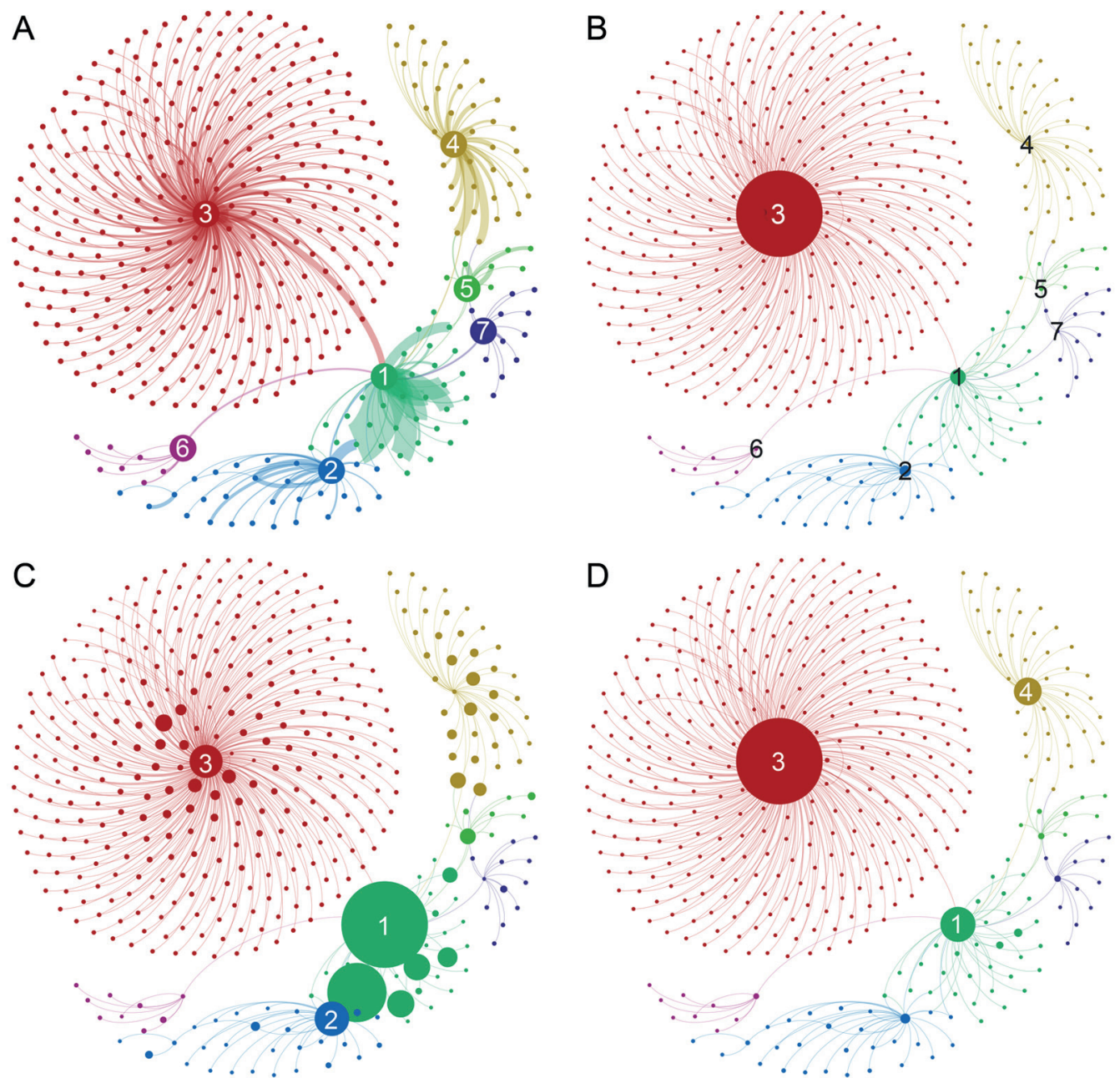

Fig.1. Animal Movement Network based on Animal Movement Permit data where each node represents a premise and each edge represents an issued AMP to or from a given premise; numbered nodes are the farms that maintained business relations with the studied farm (node \#1). (A) Modularity class (node color), number of issued AMP (edges thickness) and central premises (numbered nodes). (B) Betweenness centrality (node diameter). (C) Weighted In-degree (node diameter). (D) Weighted Out-degree (node diameter).

\section{DISCUSSION}

The prevalence of cysticercosis at the studied farm subsequently decreased after control measures were deployed, particularly the strategy of avoiding commercial trades with farms that showed a greater risk of infection, besides appropriated bovine deworming and health education.

Bovine cysticercosis is prevalent in many Brazilian regions and is highly related to regional basic sanitary condition and cattle management (Rossi et al. 2015). The initial prevalence observed at the farm $(24.9 \%)$ was higher than the prevalence reported by other authors for the same state (1.0 to 6.3\%) (Schenk \& Schenk 1982, Carmo \& Oliveira 1997, Marques et al. 2008, Rossi et al. 2015). However, after the implementation of proper control measures, the prevalence decreased to percentages comparable to the ones reported for the Mato Grosso do Sul State, indicating success for the adopted strategy. Among the adopted strategies, data obtained from the beef cattle farm together with the information registered on the Animal Movement Permits (AMPs) showing where the cattle were last located and to where it was destined, allowed us to construct a movement network and to observe a high influx of animals (Fig.1) towards node \#1 (studied area). Furthermore, in terms of a disease spread, the network diameter is the maximum number of edges that should exist, so that a disease could reach the linear size of a network (Natale et al. 2009). Hence, for the studied network, animals infected with bovine cysticercosis reached the furthermost livestock holding whenever there were at least five issued AMPs for those animals.

According to a node's modularity class, the network was divided into 7 clusters/communities with strong preferential trade among them (Fig.1A). In the cysticercosis' epidemiology these communities could indicate that infected animals tends to readily spread between the farms of a given community and later reach farms of other communities like observed for tuberculosis (Brooks-Pollock \& Keeling 2009). For each $\mathrm{f}$ these communities there is a central node, indicated by its of betweenness centrality (Fig.1B). It is a measure of how important a farm can be in a disease spread as it reflects the number of animals that passes through that farm in order to reach other farms (Martínez-López 
et al. 2009). In addition, farms with higher animal influx (in-degree) have an increased probability that at least one infected animal reach that farm (Natale et al. 2011). On the other hand, farms with higher animal departures, acts as a disease spreader, as it sends higher number of animals to other farms (Fig.1C and 1D) (Pilosof et al. 2015). Therefore, node \#3 was identified as a central point for disease dissemination to other network nodes and the studied farm/ node \#1 is a network receiver with the highest probability to receive sick animals. These findings are reinforced by the evaluation of animal movements to the node \#1 and its cysticercosis occurrence, where node \#3 had a representation of almost $70 \%$ of all animals traded with this node during 2010 (Table 2). For the same year, the relative proportion of infected carcasses was $25 \%$ (Table 1 ). In contrast, the following periods (2011-2012) showed a continued decrease in cysticercosis prevalence, due to the adoption of the strategy of avoiding commercial trades with these farms that showed a greater risk of infection. Rapid decline of the prevalence in the following periods indicates that the strategy succeeded in avoiding the entrance of infected animals to the target farm, besides the other measures such as proper drug treatment and sanitary management.

Albendazol sulphoxide drug therapy is widely used in Brazilian beef cattle farms and the use of a proper treatment protocol might also have contributed for the successful control at the studied farm, as previously reported by Biondi et al. (1999) when they observed a decrease (from $37.5 \%$ to $0 \%$ ) after the introduction of albendazol sulphoxide treatment in a feedlot farm. Barbosa et al. (2003) also reported success with albendazole sulphoxide for treating bovines experimentally infected by Taennia saginata. Nevertheless, Lopes et al. (2014) have already reported a decreasing of its efficacy on bovine cysticercosis treatment.

Although at the present AMPs are one of the main tools adopted for traceability, it does not allow individual traceability, since the information they contain concerns animal lots and their movement (Grisi-Filho et al., 2013). This system interferes with the identification of animals or beef products, where individual information is needed (Rocha \& Lopes 2002), thus hampering the control of diseases such as bovine cysticercosis.

\section{CONCLUSIONS}

The identification of farms with a putative risk of Taenia saginata infection using the animal movement network is a useful tool for controlling and preventing bovine cysticercosis, thus minimizing economic losses and preventing human taeniasis.

This study highlighted network properties that provided support information for planning strategies that could be applied to other diseases, and alerts to the importance of individual traceability as a more efficient tool for disease control and prevention.

Acknowledgements.- We thank to the farm owners José Pavan Filho and José Pavan Neto and his working team for allowing us to study the farm; to the Animal and Plant Health Defense State Agency (IAGRO); to the São Paulo State Agriculture Defense Coordination (CDASP); to the Agricultural
Institute of Minas Gerais (IMA) and to the Goiania Agency of Agricultural Protection (AgroDefesa) for the data. We also thank the reviewers for their suggestions.

Conflict of interest statement.- The authors declare there are no conflicts of interest of a financial or personal nature.

\section{REFERENCES}

Amaku M., Grisi-Filho J.H., Negreiros R.L., Dias R.A., Ferreira F., Ferreira J.S., Cipulo R.I., Marques F.S. \& Ossada F. 2015. Infectious disease surveillance in animalmovementnetworks: an approach based on the friendship paradox. Prev. Vet. Med. 121:306-313.

Barbosa F., Cabral D. \& Sopelete M. 2003. Eficácia do sulfóxido de albendazole na cisticercose bovina. Hora Vet. 22:18-20.

Biondi G.F., Henrique C.H. \& Oliveira A.C. 1999. Alto índice de cisticercose bovina, em sistema de confinamento, detectado no município de Goiânia (GO): estratégia de controle através da utilização do sulfóxido de albendazol 17\%. Hora Vet. 18:27-30.

Brasil 2006a. Instrução normativa no 17 de 13 julho 2006. Dispõe sobre as normas para as certificadoras registradas junto ao MAPA. Ministério da Agricultura Pecuária e Abastecimento. Diário Oficial da Republica Federativa do Brasil, Poder Executivo, Brasília, DF, 14 jul. 2006, Seção 1, p.25.

Brasil 2006b. Instrução normativa no 18 de 18 de julho de 2006. Aprova o modelo da Guia de Trânsito Animal (GTA) a ser utilizado em todo o território nacional para o trânsito de animais vivos, ovos férteis e outros materiais de multiplicação animal. Ministério da Agricultura Pecuária e Abastecimento. Diário Oficial da República Federativa do Brasil, Poder Executivo, Brasília, DF, 18 jul. 2006, Seção 1, p.342.

Brasil 1997. Decreto Federal 30.691 de 29 março de 1952, alterado pelos decretos 1.255 de 25/06/1962,1236 de 02/09/1994, 1812 de 08/02/1996 e 2244 de 04/06/1997. Dispõe sobre o regulamento de inspeção industrial e sanitária de produtos de origem animal. Ministério da Agricultura Pecuária e Abastecimento. Diário Oficial da República Federativa do Brasil, Poder Executivo, Brasília, DF, 04 jun. 1997, Seção 1, p.19697.

Brooks-Pollock E. \& Keeling M. 2009. Herd size and bovine tuberculosis persistence in cattle farms in Great Britain. Prev. Vet. Med. 92:360-365.

Carmo R.G. \& Oliveira J.V. 1997. Prevalência da cisticercose bovina no Estado do Mato Grosso do Sul. Hig. Aliment. 11:45-49.

Development Core Team R 2011. R: A Language and Environment for Statistical Computing. R Foundation for Statistical Computing Vienna, Austria.

Dorny P. \& Praet N. 2007. Taenia saginata in Europe. Vet. Parasitol. 149:2224.

Green D., Kiss I. \& Kao R. 2006. Modelling the initial spread of foot-andmouth disease through animal movements. Proc. R. Soc. B, Biol. Sci. 273:2729-2735.

Grisi-Filho J.H., Amaku M., Ferreira F., Dias R.A., Ferreira Neto J.S., Negreiros R.L. \& Ossada R. 2013. Detecting livestock production zones. Prev. Vet. Med. 110:304-311.

Guimarães-Peixoto R.P.M., Souza V.K., Pinto P.S.A. \& Santos T.O. 2012. Distribuição e identificação das regiões de risco para a cisticercose bovina no estado do Paraná. Pesq. Vet. Bras. 32:975-979.

IBGE 2015. Sistema IBGE de Recuperação automática (SIDRA). Inst. Bras. Geogr. e Estatística, URL http://www.sidra.ibge.gov.br/

Kao R., Danon L., Green D. \& Kiss I. 2006. Demographic structure and pathogen dynamics on the network of livestock movements in Great Britain. Proc. R. Soc. B, Biol. Sci. 273:1999-2007.

Keeling M.J., Danon L., Vernon M.C. \& House T.A. 2010. Individual identity and movement networks for disease metapopulations. Proc. Natl Acad. Sci. 107:8866-8870.

Keeling M.J. \& Eames K.T.D. 2005. Networks and epidemic models. J. R. Soc. Interface 2:295-307.

Leonard M., Graham S. \& Bonacum D. 2004. The human factor: the critical importance of effective teamwork and communication in providing safe care. Quality and Safety in Health Care, p.i85-i90. 
Lloyd S. 2014. Cysticercosis, p.1214-1224. In: World Organization for Animal Health (Ed.). Manual of Diagnostic Tests and Vaccines for Terrestrial Animals. OIE, Paris, France.

Lopes W.D.Z., Crz B.C., Soares V.E., Nunes J.L.N., Teixeira W.F.P., Maciel W.G., Buzzunili C., Pereira J.C.M., Felippelli G., Soccol V.T., Oliveira G.P. \& Costa A.J. 2014. Historic of therapeutic efficacy of albendalzole sulphoxide adminstered in different routes, dosages and tratment schemes, against Taenia saginata cysticercus in cattle experimentally infected. Exp. Parasitol. 137:14-29.

Marques G.M., Buzi K.A., Galindo L.A., Baldini E.D. \& Biondi G.F. 2008. Avaliação dos registros de condenação por cisticercose em bovinos abatidos em frigoríficos da região centro oeste do estado de São Paulo (19962000). Vet. Zootec. 15:114-120.

Martínez-López B., Perez A.M. \& Sánchez-Vizcaíno J.M. 2009. Combined application of social network and cluster detection analyses for temporal-spatial characterization of animal movements in Salamanca, Spain. Prev. Vet. Med. 91:29-38.

Natale F., Giovannini A., Savini L., Palma D., Possenti L., Fiore G. \& Calistri P. 2009. Network analysis of Italian cattle trade patterns and evaluation of risks for potential disease spread. Prev. Vet. Med. 92:341-350.

Natale F., Savini L., Giovannini A., Calistri P., Candeloro L. \& Fiore G. 2011.
Evaluation of risk and vulnerability using a Disease Flow Centrality measure in dynamic cattle trade networks. Prev. Vet. Med. 98:111-118.

Pilosof S., Morand S., Krasnov B.R. \& Nunn C.L. 2015. Potential parasite transmission in multi-host networks based on parasite sharing. PLoS One 10:e0117909.

Reis B.Y., Kohane I.S. \& Mandl K.D. 2007. An epidemiological network model for disease outbreak detection. PLoS Med. 4:e210.

Ribeiro-Lima J., Enns E.A., Thompson B.,Craft M.E. \& Wells S.J. 2015. From network analysis to risk analysis: An approach to risk-based surveillance for bovine tuberculosis in Minnesota, US. Prev. Vet. Med. 118:328-340.

Rocha J.L.P. \& Lopes M.A. 2002. Rastreabilidade e certificação da produção da carne bovina: um comparativo entre alguns sistemas. Revta Bras. Agroinformática 4:130-146.

Rossi G.A.M., Hoppe E.G.L., Mathias L.A., Martins A.M.C.V., Mussi L.A. \& Prata L.F. 2015. Bovine cysticercosis in slaughtered cattle as an indicator of good agricultural practices (GAP) and epidemiological risk factors. Prev. Vet. Med. 118:504-508.

Schenk M.A.M. \& Schenk J.A.P. 1982. Prevalência de tuberculose, cisticercose e hidatidose em bovinos abatidos nos matadouros frigoríficos do estado do Mato Grosso do Sul, Brasil (1974-1979). Comun. Téc. 11, Embrapa Gado Corte, Campo Grande/MS, p.1-4. 